\title{
Fuel Subsidy Abolition and Performance of the Sectors in Malaysia: A Computable General Equilibrium Approach
}

\author{
Loo Sze Ying ${ }^{a}$ \\ Mukaramah Harun ${ }^{b}$ \\ Universiti Utara Malaysia
}

\begin{abstract}
The attempt of abolishing fuel subsidy to alleviate the rising pressure on public finances would pose a threat to the performance of the sectors. This study, therefore, intends to identify the impact of abolishing the subsidies on domestic producers in Malaysia using a Löfgren-based computable general equilibrium (CGE) model. The findings show that the fuel subsidy abolition leads to a significant fall in the level of production, and consequently decreases output allocation for domestic and export markets. Sectors which use relatively large amounts of oil products in production would most likely be hit harder. Besides simulating the impact of abolishing the fuel subsidies, two supplementary regimes (reallocating the extra savings to the agricultural sector to assist the rural poor and transferring direct cash to those who are in need) are incorporated to deal with the decelerating growth in domestic production. Interestingly, raising agricultural investment is found to be more favourable in terms of better performance in the growth of the sector. Thus, it is advisable to include improvement of farming practices in designing policy measures. This study can further serve as a guideline in upgrading the existing subsidy abolition to ensure the performance of the sectors is wholly satisfactory.
\end{abstract}

Keywords: Agricultural investment, computable general equilibrium model, direct cash transfer, fuel subsidy abolition, output productivity

JEL classification: C68, H23, Q14, Q48

\section{Introduction}

Fuel subsidies have long been used broadly in developed and developing countries to stimulate economic development by allowing access to affordable energy services (IEA, OPEC, OECD, \& the World Bank, 2010). Usually, fuel subsidies administered by the governments take the form of low price controls of oil products made from crude oil including gasoline, kerosene, diesel oil and heavy fuel oil. The accessibility of low fuel prices is of critical importance to all sectors directly using oil products, to fuel transports to move resources and generate energy to power industrial plants, and other low-priced commodities used as inputs in production due to the transmission

a School of Economics, Finance and Banking, College of Business, Universiti Utara Malaysia, 06010 UUM Sintok, Kedah Darul Aman, Malaysia. Email: szeyingloo89@gmail.com (Corresponding author)

b School of Economics, Finance and Banking, College of Business, Universiti Utara Malaysia, 06010 UUM Sintok, Kedah Darul Aman, Malaysia. Email: mukaramah@uum.edu.my

Article Info: Received 22 October 2018; Revised 16 July 2019; Accepted 27 September 2019 https://doi.org/10.22452/MJES.vol56no2.7 
of low costs (Clements, Jung, \& Gupta, 2007; Rentschler, Kornejew, \& Bazilian, 2017). Reducing distribution cost stimulates the production level of the sectors, which in turn, expands the size of the market access. On the other hand, households will have the benefit of a more affordable cost of living with low consumer prices of goods and services brought into the market, particularly for the low-income population (El-Katiri \& Fattouch, 2015; Ellis, 2010).

However, it is worth noting that all possible benefits of fuel subsidies have become increasingly different in practice from what looks good. The fuel subsidies are widely considered as an economically inefficient regime. They induce the problem of waste and inefficiency in resource allocation (Barany \& Grigonyte, 2015; Kosmo, 1987). Low fuel prices discourage the preservation of efficient technologies that might be more economically and environmentally attractive, leading to extremely high fuel consumption in the sectors (Abdelrahim, 2014; IEA et al., 2010). Inevitably, local production patterns tend to be highly capital-intensive, or less labour-intensive, undermining energy conservation efforts. Moreover, huge fuel consumptions reveal massive subsidy bills, confronting the government's growing burden in the fiscal balance regardless of the economic growth. The fact is, the fuel subsidies do not reflect the true market prices of the supply where the governments partly financed the high costs. In light of these drawbacks, the attempt of abolishing fuel subsidies has now come to the fore.

As in other countries, the Malaysian government has been subsidising common oil products, particularly gasoline and diesel oil with sales tax exemption to ensure domestic fuel prices are below international levels. The rationale behind this is to protect the low-income population and to stimulate economic activities. The retail fuel prices fluctuated very little over the years to stabilise domestic inflationary pressures. For example, the price for the broadly used fuel RON-95 remained at RM1.90 per litre despite soaring world oil prices which averaged USD-124.57/barrel and USD126.17/barrel in 2011 and 2012 respectively (Ministry of Finance, 2013). As time went by, various unfavourable consequences arose mainly due to cross-border fuel smuggling, public budget deficits, environmental degradation, and underinvestment in the domestic energy sector. Also, the fuel subsidies have been identified as a highly inequitable distribution of wealth where about $71 \%$ of the subsidies went to the middle- and high-income population as well as foreigners (Ministry of Finance, 2011).

The fuel subsidy reform finally emerged and was highlighted in the New Economic Model (NEM) and the Tenth Malaysia Plan (2011-2015) in response to the rapidly growing budget deficit ${ }^{1}$ and with equal emphasis on environmental sustainability ${ }^{2}$. Starting 1 December 2014, the government gradually abolished subsidies for the widely used RON95 fuel and diesel and replaced it with a managed floating system whereby the retailed prices were determined based on the monthly average world price of oil. ${ }^{3}$

1 According to the Ministry of Finance (2014), the fuel subsidy created a historical high record of RM27.9 billion to retain control of the market from the extreme high world oil price shocks. The accumulation of budget deficits over the years resulted in a high national debt and deteriorating public finance.

2 The government was committed to manage non-renewable resources sustainably through appropriate pricing, regulatory and strategic policies.

3 RON97 fuel has not been subsidised since 2009. 
Recently the retail prices of fuel are reviewed and determined weekly since the end of March 2017, marking a clear commitment of abolishing fuel subsidies completely. Inevitably, enabling access to affordable fuel prices to run routine operations would come to an end. Heavy dependence upon oil products as a main combustible source to produce energy in the processing plant has put the sectors at a vulnerable position under the reform. ${ }^{4} \mathrm{~A}$ fuel price hike would drive the sectors into a big challenge of unanticipated high cost, raising the question of consequences on the performance of the sectors. Therefore, their ability to react to the subsidy abolition needs to be taken note in the moment where their competitiveness might be influenced. Often, producers are likely to reduce output volumes and raise prices to pass the higher cost on to the purchasers rather than absorb the cost burden to maximise their ultimate profits (Rentschler et al., 2017). It is an effective and fastest way to ensure high profitability remains as adopting more structural measures such as fuel substitutions require an extendable time frame and investment.

Reaching sustainable economic growth to improve economic, social and environmental affluence was always the rationale behind the government's initiation of jumping on the bandwagon of the fuel subsidy abolition (Beaten et al., 2013; Merrill \& Chung, 2014). However, a review of previous studies showed that the impact of the subsidy reform on sectors covered high volatile input costs, typically underlining that they would generate significant impacts on the production, domestic sales, export and import (Akinyemi, Alege, Ajayi, Adediran, \& Urhie, 2017; Hamid \& Rashid, 2012; Sayed, Sayegh, Saliba, \& Stephen, 2015; Siddiq, Minor, Grethe, Aguiar, \& Walmsley, 2015). In contrast to the household impacts of the fuel subsidy reform that are increasingly well-documented, the producers' response has largely been ignored (Rentschler et al., 2017). Hence, this paper seeks to fill this gap by extending the impacts of the sectors on activity (production) level, import and marketed output (covers domestic sales and export). In particular, this paper considers two saving reallocation regimes. The additional subsidy savings are reinvested into the agricultural sector, or are placed on the direct cash assistance scheme to minimise the cost burden of the poor during the transitional period of the reform. The agricultural sector is focussed with the objective of helping the rural poor where they are mostly involved in agricultural activities (Bekhet, 2010; Cervantes-Godoy \& Dewbre, 2010; Solaymani, Kari, \& Zakaria, 2013), and strengthening the domestic supply chain since they are identified as high interindustrial linkage sectors (Bekhet, 2010; Holland, Figueroa, \& Gilbert, 2001; Jaafar, Salleh, \& Manaf, 2015). For this purpose, the input-output analysis is to identify the impacts of fuel subsidies especially on those (producers) absorbing large amounts of fuel products, whereas a Malaysian computable general equilibrium (CGE) model, that takes account of direct and indirect economic effects, is performed to undertake the simulated analysis.

The remaining structure of the paper is as follows. Section 2 discusses the literature reviews. Section 3 covers the research methodology used in structuring the CGE model

4 Out of 51,806 ktoe of oil consumption, the industrial sector covering the agriculture, mining, manufacturing and construction sectors consumed 20,826 ktoe $(40.2 \%)$ where oil products remained the largest source of energy (Malaysia Energy Information Hub Unit, 2018). 
where the research framework, model specifications and model simulations that were designed are discussed, together with the model simulations and data sources that were used. Section 4 presents the findings of the study. The last section contains the concluding remarks and recommendations.

\section{Literature Review}

Regardless of how the fuel subsidy abolition is measured, the fuel subsidy reform often comes with decreases in the production level of the sectors that are affected by increasing the market prices of the outputs, which in turn, reduced its demands in substantial rates (Akinyemi et al., 2017; Clements, Jung, \& Gupta, 2007; Hamid \& Rashid, 2012; Manzoor, Shahmoradi, \& Haqiqi, 2012; Saari, Shuja, \& Rahman, 2013; Siddiq et al., 2015; Solaymani, Kardooni, Kari, \& Yusoff, 2014). The fact is that fuel subsidies make up a large portion of input costs. When fuel subsidies are abolished, the sectors are discouraged to produce more, but raise the output prices to pass the increased costs to purchasers. Thus, several studies have found that the prices of the outputs produced by the affected sectors tended to be higher under the subsidy reform. For instance, Hamid and Rashid (2012) who used an integrated approach of the input-output analysis and CGE model for Malaysia found that output prices for the manufacturing, transportation and fishery sectors were rather high due to the heavy use of oil products in production activities. Specifically, Siddiq et al.'s (2015) study, based on the global applied general equilibrium model with 21 aggregated Global Trade Analysis Project (GTAP) sectors, showed that the soaring prices of the outputs of the transport-communication and electricity sectors had their output demands reduced remarkably as oil prices stood at $31.7 \%$ and $23.7 \%$ of their input costs respectively. Therefore, the occurrence of a high inflationary pressure in the market can always be traced to the reform.

Where possible, mitigating measures should be included in the reform to deal with barriers to meet with success in the subsidy reform. High utilisation of fuel subsidies imparted a distinctive favour to the complete abolishment of fuel subsidies in previous studies, conveying more fiscal space for other transfer schemes. Manzoor et al. (2012) noted how large the oil subsidies were in Iran and that the subsidy reform would raise the prices highly, between $140 \%$ (for gasoline) and $2797 \%$ (for liquid gas). Siddiq et al. (2015) also claimed that the subsidies on imported fuels stood at about $80 \%$ of the Nigerian energy market. The complete abolishment of fuel subsidies is desirable where the additional savings can be placed on high-priority measures (Clements et al., 2007; Cockburn, Robichaud, \& Tiberti, 2018; Dabla-Norris, Kochhar, Suphaphiphat, Ricka \& Tsounta, 2015; IEA et al., 2010; Laderchi, 2014). The additional subsidy savings could be re-injected into the economic system using autonomous expenditures (Hamid \& Rashid, 2012). The appropriate saving reallocations can produce short- and long-term economic benefits (Widodo, Sahadewo, Setiastuti, \& Chaerriyah, 2012). Previous studies showed a great improvement in the performance of the sectors with the savings reallocated to the productive sectors (Akinyemi et al., 2017; Hamid \& Rashid, 2012; Rentschler, 2016; Sayed et al., 2015; Siddiq et al., 2015; Widodo et al., 2012). Using a survey questionnaire, Kehinde, Kyade, Felix, Musibau and Ishola (2012) claimed that the huge effect that hit the agricultural sector could be cushioned 
through an effective investment in the sector. Also focussing only the agricultural sector, Akinyemi et al. (2017) extended further the fund allocation to infrastructural and technological development in the long term. They declared that it was very impressive in strengthening the food and agricultural performance (positive effects for food exports and imports and the exports of agricultural products) due to its increased rate in agricultural output, albeit the one shot subsidy removal brought an upward movement in the short-term price level. Direct injection of government funds into the sectors could subsequently speed up private investments to turn out substantial benefits in the market. Thus, the sectors were anticipated to perform well under the fund transfer targeting the productive sector that was selected in response to the fuel subsidy abolition than the counterpart with cash assistance.

Such a reallocation stands in contrast to the direct cash assistance that was imposed under the reform, and aims at protecting the consumption level of the targeted recipients against high price levels (Cockburn et al., 2018; Cooke, Hague, Tiberti, Cockburn, \& El Lahga, 2015; El-Katiri \& Fattouch, 2015; Feltenstein, 2017; Feng, Hubacek, Liu, Marchán, \& Vogt-Schilb, 2018; IEA et al., 2010; Laderchi, 2014). Cockburn et al. (2018) found that the poverty increases due to fuel subsidy cuts in Egypt and Jordan could be offset if the saving reallocation of the cash transfer was put into practice. Besides, Siddiq, et al. (2015) underlined the greatest effect of the fund transfer targeting the oil refinery sector, yet, the provision of cash assistance to poor households had a relatively fair improvement in domestic production.

\section{Research Methodology}

Considering the subject of fuel subsidy abolition, fuel input coefficients are the first to be calculated using a simple input-output analysis to provide information on the quantity of fuel products required to produce one dollar's worth of output of a given sector. The analysis enables a detailed presentation of the impacts of fuel subsidies especially on those consuming sizeable amounts of fuel products such as gasoline and diesel produced in the oil refinery sector. This demand relationship is derived directly from the Malaysia input-output table for 2010. The sectors that require large amounts of fuel products to produce goods and services would receive rather high amounts of fuel subsidies. The proportions in which the fuel products that are consumed in producing goods and services of a particular sector, are assumed to be constant over time.

The calculations are based on the following simple equation.

$$
a_{f j}=\frac{x_{f j}}{X_{j}}
$$

where $a_{f j}$ denotes the unit input coefficient of the fuel product $(f)$ to sector $j, x_{f j}$ denotes the indices of the fuel product used as input for sector $j, X_{j}$ denotes the total output of sector $j$.

The input-output model gives only a picture of the production process in an economic system in terms of the inter-sector flow of inputs and outputs, ignoring the flow of income and expenditure of economic agents. It is a set of linear simultaneous equations with the assumptions of exogenous prices and homogeneous inputs across 
the sectors. Thus, a CGE model is developed with a compilation of linear and non-linear simultaneous equations to deal with those limitations that have been discussed. The CGE model captures the equilibrium in the markets of factors, products and institutions taking into account the fluctuating variables of prices and quantities. For practical policy analysis, the CGE model is employed in this study.

\subsection{CGE Modelling Framework}

A comparative static CGE model is used to capture the implication of fuel subsidy reform on the activity level of the sectors (QA), the use of imported intermediates (QM) and the allocation of the aggregated domestic outputs on domestic and export markets (QX). The International Food Policy Research Institute (IFPRI) CGE modelling framework, developed by Löfgren, Lee and Robinson (2002), is adopted with a few modifications and assumptions to suit the objectives of this study.

The model is developed with four core institutions. First, firms receive incomes from production factors and transfers from other institutions. Although they are not consume, but firms still spend their incomes on direct taxes, savings and transfers to other institutions. Second, households have their incomes mainly from production factors and transfers from other institutions. These incomes are then allocated on consumption, savings, tax payments, and maybe, transfers to other institutions. Following this is the government income that is generated mainly from other institutions' payments through direct and indirect taxes and transfers. Government incomes are then spent judiciously on consumption, subsidies and transfers for other institutions to avoid excessive fiscal spending. The difference between current fiscal revenue and expenditure define the fiscal balance where the government saving is flexible and direct taxes are fixed. Therefore, any fuel subsidy abolition (by raising sales tax in the manufacturing oil refinery sector) would definitely give rise to fiscal saving and this extra will be spent in exactly the same proportions to selected saving reallocations. Last but not least, trade balance and transfers from or to the rest of the world (ROW) - termed the transaction pattern of foreign sector. The foreign savings are measured by distinguishing foreign currency spending and receipt. Any foreign transaction is fixed in foreign currency. Thus, the balance in foreign market is determined only by exports and imports.

There is a set of model constraints bound to the fixed coefficients for economic behaviour such as subsidy rate, following the neoclassical-structuralist IFPRI modelling. To equal the supplies and demands in factor market, the quantity of each supply factor is assumed exogenous and mobile under full employment environment. Besides, the assumption of fixed foreign savings and flexible real exchange rate is held since Malaysia is a small open economy. Linking the specification of savings-driven investment to all non-government institutions has demonstrated the constant marginal propensity to save (MPS) among non-government institutions. In other words, flexible capital formation is adjusted to equalise with the saving value.

Equations that represent the economic mechanism interactions are derived and introduced as follows, covering four blocks of equations, consisting of the production and trade block, price block, institution block and system constraint block. 


\section{(i) Production and trade block}

The producer has not only decided the input combination between intermediate inputs and factors, but also the factors' combination (to equal the marginal revenue product and wages, which might be different across activities) at the activity level to increase the technological efficiency in the production process. Thus, a two-level nested production function is adopted (illustrated in equations (2) and (3)) with Leontief production function at the top-level production activity and the constant elasticity of substitution (CES) production function at the bottom-level production activity, consisting of the aggregate value added and intermediate inputs.

$$
\begin{array}{ll}
Q V A_{a}=i v a_{a} \bullet Q A_{a} & a \in A L E O N \\
\operatorname{QINTA}_{a}=\operatorname{int} a_{a} \bullet Q A_{a} & a \in A L E O N
\end{array}
$$

Equation (4) reveals the quantity of value-added for each activity (QVA). It is a CES function of disaggregated quantities of factors of labour, capital and intermediate inputs. Equation (5) shows the factor demand for activities where the activity-specific factor prices and the net of the intermediate input costs are defined on the right- and the left-hand sides. A zero profit condition is reached where each activity demanded a set of factor inputs (QF) at the point where the marginal revenue product equals the factor prices. The disaggregated intermediate input demand for each activity (QINT) in Equation (6) is derived from the multiplication of the level of the aggregate intermediate input use (QINTA) and a fixed intermediate input coefficient (ica).

$$
\begin{array}{cl}
Q V A_{a}=\alpha_{a}^{v a} \bullet\left(\sum_{f \in F} \delta_{f, a}^{v a} \bullet Q F_{f, a}^{-\rho_{a}^{v a}}\right)^{-\frac{1}{\rho_{a}^{v a}}} & a \in A \\
W F_{f} \bullet \overline{W F D I S T}_{f, a}=P V A_{a}\left(1-t v a_{a}\right) \bullet Q V A_{a} \bullet & \\
\left(\sum_{f \in F^{\prime}} \delta_{f, a}^{v a} \bullet Q F_{f, a}^{-\rho_{a}^{v a}}\right)^{-1} \bullet \delta_{f, a}^{v a} \bullet Q F_{f, a}^{-\left(\rho_{a}^{v a}+1\right)} & a \in A ; f \in F \\
Q I N T_{c, a}=i c a_{c, a} \bullet Q I N T A_{a} & a \in A, c \in C
\end{array}
$$

Then, equation (7) shows a constant elasticity of transformation (CET) aggregate of the marketed output levels of the diverse production activities.

$$
Q X_{a, c}=\theta_{a, c} \bullet Q A_{a} \quad a \in A, c \in C X
$$

To achieve profit maximisation, the allocation of the aggregated domestic outputs on export and domestic market is made subject to CET function, exhibited in equations (8) and (9). The export demand is infinitely elastic at a given world price and its prices are set by including the transaction costs to the border and export taxes. In the domestic market, without counting the marketing costs of domestic sales, the supply price equals the price paid by domestic demanders. On the other hand, used inputs 
of composite commodity that is a combination of imports and domestic outputs are chosen subject to the Armington function, exhibited in equations (10) and (11). Exponent $\rho$ is the elasticity of substitution in the functions.

$$
\begin{array}{ll}
Q X_{C}=\alpha_{c}^{t} \bullet\left(\delta_{c}^{t} \bullet Q E_{c}^{\rho_{c}^{t}}+\left(1-\delta_{c}^{t}\right) \bullet Q D_{c}^{\rho_{c}^{t}}\right)^{\frac{1}{\rho_{c}^{t}}} & c \in(C E \cap C D) \\
\frac{Q E_{c}}{Q D_{c}}=\left(\frac{P E_{c}}{P D_{c}} \bullet \frac{1-\delta_{c}^{t}}{\delta_{c}^{t}}\right)^{\frac{1}{\rho_{c}^{t}-1}} & c \in(C E \cap C D) \\
Q Q_{c}=\alpha_{c}^{q} \bullet\left(\delta_{c}^{q} \bullet Q M_{c}^{-\rho_{c}^{q}}+\left(1-\delta_{c}^{q}\right) \bullet Q D_{c}^{-\rho_{c}^{q}}\right)^{-\frac{1}{\rho_{c}^{q}}} & c \in(C M \cap C D) \\
\frac{Q M_{c}}{Q D_{c}}=\left(\frac{P D_{c}}{P M_{c}} \bullet \frac{\delta_{c}^{q}}{1-\delta_{c}^{q}}\right)^{-\frac{1}{1-\rho_{c}^{q}}} &
\end{array}
$$

(ii) Price block

This block links the endogenous prices to other connected prices (either endogenous or exogenous) and non-price model variables. Consumer price index (CPI) for the domestically marketed output (the model numéraire) that was fixed is defined in Equation (12). In other words, the model is homogeneous of degree zero in prices where all prices get double increases for a doubling of the value of the numéraire but all quantities remained fixed. Equation (13) indicates the producer price index (DPI) for the domestically produced outputs. The activity price in Equation (14) is the gross revenue per unit while the aggregate intermediate input cost in Equation (15) is the product of the composite commodity prices and the intermediate input coefficients. Equation (16) reflects the net revenue of taxes for each activity representing the expenditure of value-added and intermediate inputs.

$$
\begin{array}{ll}
\overline{C P I}=\sum_{c \in C} P Q_{c} \bullet c w t s_{c} & \\
D P I=\sum_{c \in C} P D_{C} \bullet d w s t_{c} & \\
P A_{a}=\sum_{c \in C} P X_{a, c} \bullet \theta_{a, c} & a \in A \\
P I N T A_{a}=\sum_{c \in C} P Q_{c} \bullet i c a_{c, a} & a \in A \\
P A_{a} \bullet\left(1-t a_{a}\right) \bullet Q A_{a}=P V A_{a} \bullet Q V A_{a}+P I N T A_{a} \bullet Q I N T A_{a} & a \in A
\end{array}
$$


Following this, the constant import price is determined in equation (17) since Malaysia is a small country. It is decided by world import prices $\left(p w m_{c}\right)$, exchange rate $(E X R)$ and import tariff $\left(t m_{c}\right)$. On the other side, export prices for selling domestic outputs out of Malaysia in equation (18) are determined by world export prices (pwe), exchange rate (EXR) and export tax (te). For the domestic market, spending on domestic output and imports in equation (19) is all measured in domestic demand prices, excluding sales tax.

$$
\begin{array}{ll}
P M_{C}=p w m_{c} \bullet E X R\left(1+t m_{c}\right) & c \in C M \\
P E_{C}=\left(1-t e_{c}\right) p w e \bullet E X R & c \in C E \\
P Q_{C} \bullet\left(1-t q_{c}\right) \bullet Q Q_{c}=P D_{c} \bullet Q D_{c}+P M_{c} \bullet Q M_{c} & c \in(C D \cap C M)
\end{array}
$$

(iii) Institution block

The income and expenditure flows of inter-institutions in the social accounting matrix (SAM) are presented in functional forms. Equations (20) and (21) reflect the total factor incomes of each factor and the factor incomes of domestic institutions. Equation (22) explores the total transfers within the domestic institutions (TRNSFR) excepting the government with the fixed rate of direct taxes while Equation (23) defines the investment demand for each commodity in the market.

$$
\begin{aligned}
& Y F_{f}=\sum_{a \in A} W F_{f} \bullet \overline{W F D I S T}_{f, a} \bullet Q F_{f, a} \quad f \in F \\
& Y I F_{i, f}=\operatorname{shif}_{i, f} \bullet\left[\left(1-t f_{f}\right) \bullet Y F_{f}-t r_{r o w, f} \bullet E X R\right] \quad i \in I N S D ; f \in F \\
& \operatorname{TRNSFR}_{i, i^{\prime}}=\operatorname{shii}_{i, i^{\prime}} \bullet\left(1-\operatorname{MPS}_{i^{\prime}}\right) \bullet\left(1-\operatorname{TINS}_{h}\right) \bullet Y I_{h} \quad i \in I N S D N G ; i^{\prime} \in I N S D N G^{\prime} \\
& Q I N V_{c}=I A D J \bullet \overline{q i n v} \quad c \in C
\end{aligned}
$$

Equations (24) and (25) explain the income source of the households and firms from the factor endowments and transfers. The household consumption expenditures $(\mathrm{QHOH})$ are then illustrated in Equation (26), after paying direct taxes, savings and necessary transfers. Equation (27) shows the distribution of incomes for the firms that do not consume.

$$
\begin{array}{ll}
Y H O H_{h}=\sum_{f \in F} Y I F_{h, f}+t r_{h, \text { gov }}+E X R \bullet t r_{h, \text { row }} & h \in H \\
Y E N T_{\text {ent }}=\sum_{f \in F} Y I F_{\text {ent }, f}+t r_{\text {ent }, \text { gov }}+t r_{\text {ent }, \text { row }} \bullet E X R & \text { ent } \in \text { ENT } \\
\mathrm{QHOH}_{h}=\left(1-\sum_{i \in I N S D N G} s h i i_{i, h}\right) \bullet\left(1-M P S_{h}\right) \bullet\left(1-T I N S_{h}\right) \bullet Y H_{h} & h \in H \\
E S A V_{\text {ent }}=Y E N T_{\text {ent }}-\left(T I N S_{\text {ent }} \bullet Y E N T_{\text {ent }}\right)-t r_{\text {row,ent }} \bullet E X R & \text { ent } \in \text { ENT }
\end{array}
$$


Total government revenue (YGOV) includes the collection of direct taxes, factor incomes and transfers from the ROW in equation (28). Meanwhile, total government expenditure (EGOV) in equation (29) is the sum value of government expenditures place on consumption and transfers to non-governmental institutions and the ROW.

$$
\begin{aligned}
Y G O V= & \sum_{i \in I N S D N G} T I N S_{i} \bullet Y I_{i}+\sum_{f \in F} t f_{f} \bullet Y F_{f}+\sum_{a \in A} t a_{a} \bullet P A_{a} \bullet Q A_{a}+\sum_{c \in C} t q_{c} \bullet P Q_{c} \bullet Q Q_{c} \\
& +\sum_{c \in C E} t e_{c} \bullet p w e_{c} \bullet Q E x_{c} \bullet E X R+\sum_{c \in C M} t m_{c} \bullet p w m_{c} \bullet Q \operatorname{Im}_{c} \bullet E X R \\
& +\sum_{f \in F} Y I F_{g o v, f}+t r_{g o v, r o w} \bullet E X R \\
E G O V= & \sum_{c \in C} P Q_{c} \bullet Q G O V_{c}+\sum_{i^{\prime} \in I N S D N G} t r_{i, g o v} \bullet C P I
\end{aligned}
$$

(iv) System constraint block

This block presents the market equilibriums in functional forms. Equation (30) imposes the factor market's equilibrium between the total quantity demanded and the total quantity supplied for each factor (is fixed). The block of composite commodity markets in equation (31) places equality between quantities supplied and demanded of the composite commodity. In detail, government consumption, investment demand and stock changes are exogenous terms, whereas the remainder (the demand of intermediate use and household consumption) are endogenous terms. Following this is current account balance for the ROW (equation 32) equalising the country's earning and spending of foreign exchange in terms of foreign currency. The flexible (real) exchange rate $(E X R)$ determines the equilibrium of current account since the foreign savings (FSAV) and trade deficit are fixed in the market-clearing condition of the study.

$$
\begin{aligned}
& \sum_{a \in A} Q F_{f, a}=\overline{Q F S}_{f} \\
& Q Q_{c}=\sum_{a \in A} Q I N T_{c, a}+\sum_{h \in H} Q H O H_{c, h}+Q G O V_{c}+Q I N V_{c}+q d s t_{c}+Q T_{c} \\
& \sum_{c \in C M} p w m_{c} \bullet Q M_{c}+\sum_{f \in F} t r_{r o w, f}=\sum_{c \in C E} p w e_{c} \bullet Q E x_{c}+\sum_{i \in I N S D} t r_{i, r o w}+\overline{F S A V}
\end{aligned}
$$

The government balance in Equation (33) is to equal the government revenue and the sum of government expenditure and saving for the current year, yet the government investment is excluded. To gain a square CGE model, an extra element of Walrasian is added to Equation (34) of the saving-investment balance.

$$
Y G O V=\mathrm{E}=E G O V+G S A V
$$




$$
\begin{aligned}
& \sum_{h \in H} M P S_{h} \bullet\left(1-T_{I N S_{h}}\right) \bullet Y H_{h}+E S A V_{e n t}+G S A V+E X R \bullet \overline{F S A V} \\
& =\sum_{c \in C} P Q_{c} \bullet Q I N V_{c}+W A L R A S
\end{aligned}
$$

The total absorption in Equation (35) refers to the sum value of the domestic final demands. The fixed ratios of nominal absorption for government consumption and investment (GOVSHR and INVSHR) at equilibrium are imposed in Equations (36) and (37). The following three equations are introduced to specify the saving-investment closures.

$$
\begin{aligned}
& T A B S=\sum_{h \in H} \sum_{c \in C} P Q_{c} \bullet Q H O H_{c, h}+\sum_{c \in C} P Q_{c} \bullet Q G O V_{c}+\sum_{c \in C} P Q_{c} \bullet Q I N V_{c}+\sum_{c \in C} P Q \bullet q d s t_{c} \\
& G O V S H R \bullet T A B S=\sum_{c \in C} P Q_{c} \bullet Q G O V_{c} \\
& I N V S H R \bullet T A B S=\sum_{c \in C} P Q_{c} \bullet Q I N V_{c}+\sum_{c \in C} P Q_{c} \bullet q d s t_{c}
\end{aligned}
$$

\subsection{Model Simulations and Data Sources}

Four simulations are created to simulate the implication of abolishing fuel subsidies on output performance. The first simulation (Scenario1, C 01) is that fuel subsidies are abolished by $50 \%$, and $100 \%$ in the second simulation (Scenario2, C 02). The third simulation (Scenarion3, C 03) captures the incorporation of the incremental investment on the agricultural sector into the $100 \%$ subsidy abolition. Lastly, the fourth simulation (Scenario4, C 04) traces the incorporation of the direct cash transfer into the $100 \%$ subsidy abolition. This study treats the sales tax rate of oil refinery commodities as the parameter change and increases with equal size of government fuel subsidy abolition. To see clearly the extent of the further subsidy saving reallocations affecting the performance of the sectors, the increments for both the agricultural investment (by increasing intermediate inputs used in the production) and the cash transfer assistance (directed to the population as just a one-off) are the same amount with the extra savings coming from the fuel subsidy abolition. All simulated scenarios are then brought under the same economic environment where all markets are operated under prefect competition, only relative price matters and market-clearing conditions.

The model is formulated mainly from the SAM, which is created using the inputoutput table for the base year of 2010. Thus, the reference year for calibrating the benchmark simulation model is 2010 . Other than that, household survey reports and national account statistics (including yearly national products and expenditure accounts, balance of payments, and distribution and use of income accounts and capital accounts) are important secondary data in setting up the model. The SAM model contains accounts of activities and commodities for the sectors, together with two factors of labour and capital, indirect tax, firm, households, the government, 
saving-investment and the foreign sector (which was rest of world, ROW). For the focus of the study, an aggregate of 17 sectors of activities and commodities (agriculture, mining and quarrying, dairy product manufacturing, food processing, food and beverage manufacturing, textile and leather manufacturing, wood product manufacturing, tobacco, paper products and printing manufacturing, rubber and chemical product manufacturing, material manufacturing, electrical and electronic product manufacturing, oil refinery manufacturing, machine, vehicles and other manufacturing, energies, construction, transportation, and services) are included. This aggregate came originally from the 2010 Malaysia input-output table that consisted of 124 by 124 sectors of activity and commodity. The SAM model used is slightly different with those that was developed in the practical analysis in studies such as Mukaramah, Zakariah, and Azali (2012) and Hassan, Saari, Utit, Hassan and Mukaramah (2016), in that the separation of commodities and activities are adopted for the SAM model in this study. In other words, any commodity is produced by a series of activities and any activity produces multiple commodities where an activity represents a producer.

The SAM model is used to define those parameter values in the CGE model with the initial prices of factor and commodity being equal to one. Also, other elasticity values such as elasticity of substitution between capital and labour, and output allocations are obtained primarily from Solaymani et al. (2014). Then, the General Algebraic Modeling System (GAMS) software is used to solve all the complex mathematical functions for the purpose of analysis in this study.

\section{Findings and Discussions}

Table 1 indicates the fuel input coefficients by sectors based on the simple input-output analysis. The fuel input coefficients reveal the proportion of the input of oil products required to produce one ringgit worth of output. The findings show that the mining and quarrying sector, the energies sector, and the transportation sector are the top three sectors consuming vast amounts of oil products in creating goods and services. The transportation sector which includes many modes covering a wide range of land, water and air transport, public transport, trucks, air planes and many others, is the major consumer of fuel to provide passenger and freight transportation services. The mining and quarrying sector is the second largest consumer of fuel for its mineral extraction and logistic support, and is followed by the energies sector for electricity generation. These sectors consume substantial amounts of oil products like gasoline and diesel in the activity level (production). In other words, subsidy comprises a large proportion of their input costs for every ringgit spent for the purchase of oil products, making them especially vulnerable to the fuel subsidy reform. The fuel subsidy abolition makes purchase prices of the fuel products relatively more expensive than previously. Therefore, these sectors that are heavily dependent on oil products come at high costs, influencing their decision-making process in their production.

Table 2 indicates the percentage of changes in the performance of the sectors using the indicators of activity level (QA), import quantities (QM) and marketed output quantities (QE+QD) representing the export and domestic sales in response to the subsidy reform. Ultimate results are reported and compared with the calibration year of 2010. 
Table 1. Fuel input coefficients by sectors

\begin{tabular}{lc}
\hline Sectors & Input shares \\
\hline Agriculture & 0.120 \\
Mining and quarrying & 0.213 \\
Dairy product manufacturing & 0.006 \\
Food processing & 0.004 \\
Food and beverage manufacturing & 0.007 \\
Textile and leather manufacturing & 0.012 \\
Wood product manufacturing & 0.011 \\
Tobacco, paper products and printing manufacturing & 0.012 \\
Rubber and chemical product manufacturing & 0.053 \\
Material manufacturing & 0.058 \\
Electrical and electronic product manufacturing & 0.007 \\
Oil refinery manufacturing & 0.012 \\
Machine, vehicles and other manufacturing & 0.005 \\
Energies & 0.161 \\
Construction & 0.048 \\
Transportation & 0.270 \\
Services & 0.026 \\
\hline
\end{tabular}

Source: Author's calculation based on the input-output analysis.

Based on Table 2, the findings in Scenarios 1 (half fuel subsidy abolition) and 2 (complete fuel subsidy abolition) are almost the same with a very slight different rate. The rationale behind this is that producers tend to raise the purchase prices than make any adjustment in output production where the adjustment of investment behaviour to more structural measures to reduce the downside risk of the subsidy reform requires a great deal of time and effort (Rentschler \& Bazilian, 2017; Rentschler et al., 2017). Therefore, by focusing on the output performance by sectors, it is reasonable to infer that the impacts of half and complete subsidy abolition are not much different in the short term (the reference period).

The fuel subsidy abolition has an overall negative impact on the domestic performance of the sectors with an average drop of $4.92 \%$ in the level of activity, lowering the usage of imported inputs in production. Inevitably, less aggregated domestic outputs are created for markets for export and domestic sales. Sectors that are heavily reliant on oil products would be adversely affected, especially the transportation sector and the mining and quarrying sector. Moreover, the manufacturing sector of wood products would be affected most negatively compared with other sectors. Dropping activity level would demand less imports used as input, creating less marketed outputs. The fact is that this sector which is dominated by locally-owned enterprises mainly focusing on primary processing activities puts them in a very vulnerable position under the subsidy reform. 


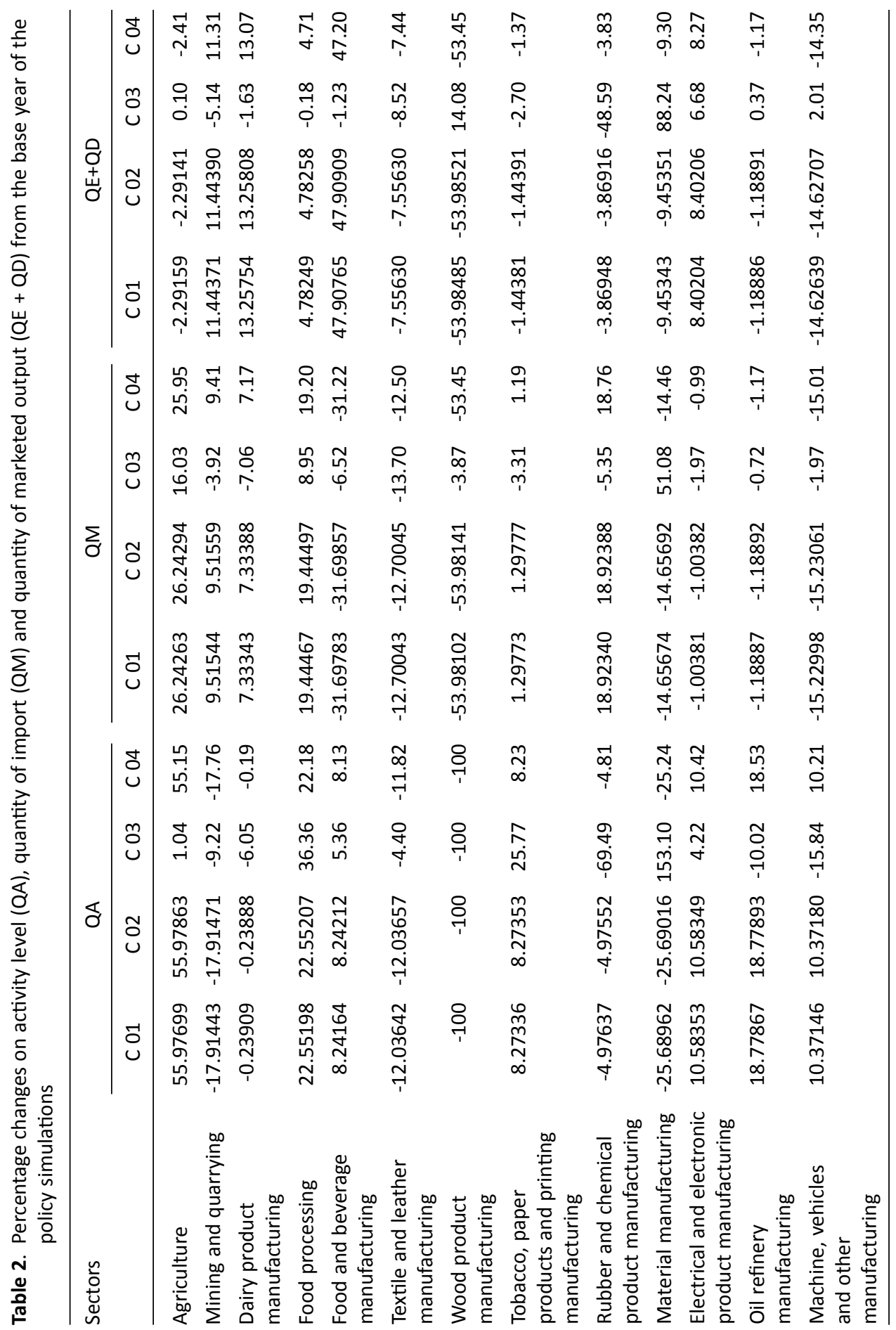


Fuel Subsidy Abolition and Performance of the Sectors in Malaysia: A CGE Approach

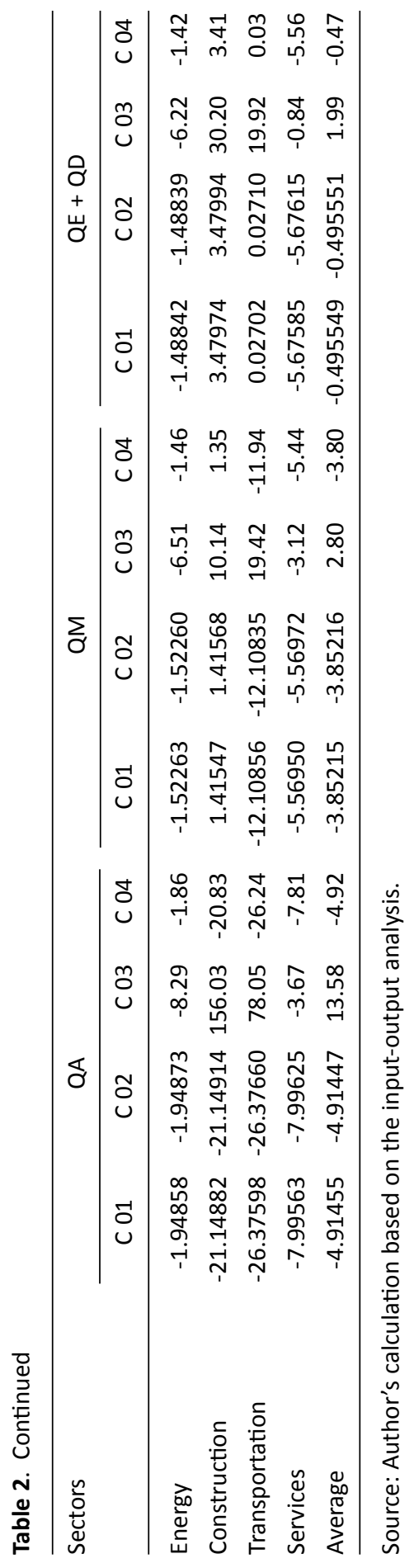


On the contrary, the increased level of activity incurred in the agricultural sector against the subsidy reform reflects its labour-intensive production processes (as found in Saari, Radam, \& Abdullah, 2008). Demands on imported inputs increase concurrently with use in the production process. However, the increase in the level of activity is not followed by the expanding allocation of marketed outputs, possibly because of the decrease in final demand, either domestically or internationally, for the agricultural products. Specifically, rubber and palm oil which are dominant agricultural products for export in Malaysia, are greatly affected by external shocks. For example, the reduction of the export tax levy on palm products in Indonesia in 2011 reduced export competitiveness of palm products for Malaysia (Choo, 2016).

Subsidy abolition with the reallocation of the savings to the agricultural sector, represented by the increase in the use of intermediate inputs in the agricultural production process, is a profound incentive to overall performance of the sectors (the total percentage of changes in the production of the sectors for Scenario 3 is the highest as compared to Scenarios 1 and 2). A sharp increase in the level of activity, associated with the growing usage of imported inputs in production, lead to higher marketed outputs that were produced. Nevertheless, for the agricultural sector specifically, the provision of additional fund transfer is inadequate to enhance its production activities as expected. There is a slight increase in rate of $1.04 \%$. Still, the additional fund transfer is an incentive to the agricultural sector to increase the usage of imported inputs to enable the sector to expand its allocation of marketed outputs.

Meanwhile, the construction sector and the manufacturing sector of materials are remarkably positively affected in comparison with other sectors, under the effort of funding the agricultural sector. The reason behind this growth is that both sectors serve as complementary sectors to other sectors in the economy. For example, the manufacturing sector of materials provides materials such as iron, steel and metal to be used not only in agricultural processing, but also for construction purposes. Hence, the output allocation for markets improved in both sectors with the rapid expansion of the activity level, associated with an increasing usage of imported intermediates in production. Nevertheless, the expanding agricultural marketed outputs are not followed by a comparable improvement in the agro-based manufacturing sectors, ${ }^{5}$ indicating insufficient agricultural supplies to meet the domestic needs of the sectors. This subject has been highlighted in the latest National Agro-food Policy (2011-2020) (Ministry of Agriculture Malaysia, 2011) which encouraged increasing productivity through the intensive use of agricultural factors in the efforts of strengthening the product value chains.

The integration of increasing direct cash transfer to those in need with complete fuel subsidy abolition in Scenario 3 has only minimal performance effects in all sectors, compared to the previous incremental agricultural investment that was discussed. The additional nominal incomes funded by the government which enabled the recipients to spend more was insufficient to generate higher economic activity (Ahmad, Rohana, \& Jamaliah, 2013). In other words, this fiscal effort has an insufficient effect on the

5 The agro-based manufacturing sectors require substantial amounts of agricultural outputs as their inputs to produce value-added outputs, including sectors of dairy product, food processing, food and beverage, textile and leather, wood product, rubber product, together with tobacco, paper products and printing in this study. 
performance of the sectors in the reference period. The adverse impacts on the performance of the sectors that happened under the complete subsidy abolition are minimised only slightly.

\section{Conclusion}

When it comes to fuel subsidy abolition, all economic decisions are subject to marketbased pricing mechanisms, causing a challenge to the value added in production due to the crucial role that fuel plays in the economy. This study investigates the impact of abolishing the decade-old fuel subsidies on the performance of the sectors in Malaysia. The CGE model is developed to simulate the impacts which such reform might have on the activity level, quantities of imports used in production and quantities of domestically-produced outputs that are further marketed to global and domestic markets. Specifically, the fuel subsidy abolition is generated by raising the sales tax of oil refinery commodities with the same amount of funds the government provide on fuel subsidies. This study includes two savings reallocations into the completed subsidy abolition; direct investment in the agricultural sector through incremental intermediate inputs, and direct cash transfers for those who are in need.

Overall, producers prefer to lower the level of production to cope with the fuel price hike, especially in the short term. It is particularly significant for those who use rather high proportions of oil products in producing goods and services. The effects that hit the sectors, however, can be shielded if the additional saving is directed to effective mitigating measures such as providing the saving reallocation to agricultural sector.

This study shows that fuel subsidy abolition would restrict the performance of the domestic sectors. The level of activity of the sectors falls sharply, demanding less imported intermediated inputs, which in turn, reduces domestic outputs that entered the markets. Specifically, sectors with substantial usage of fuel products, especially the transportation sector, would find themselves relatively vulnerable to the reform. Nonetheless, the inclusion of the reallocation of further savings into the reform improved overall performance of the sectors. The ultimate findings reveal that the association of the fund transfer to the agricultural sector has a stimulating effect on the performance of the domestic sectors in comparison with direct cash assistance for targeted segments. With the additional fund transfer, the agricultural sector would be able to create more competitive commodities which serve as intermediate inputs or final goods with the rising demands of raw materials from other complementary sectors. Thus, it would have great impacts on the economy.

Despite this, an extension of this study, that is not considered as one of the alternative supplementary approaches, is the coupling of the fuel subsidy abolition with developing possible energy substitution in acknowledgement of the climate change. For example, renewable energy that is environmentally friendly can be used as one of the combustible sources in generating electricity (for household daily use) or producing goods and services (for value-added production activity). The availability of a second energy choice (especially non-fossil fuels) will not only eliminate the need for future subsidies, but also the negative externalities brought by the uncontrollable excessive fossil-fuel consumption. 


\section{References}

Abdelrahim, K.E. (2014). Economic impact of energy subsidy and subsidy reform measures: New evidence from Jordan. International Journal of Business and Social Research, 4(4), 98-110.

Ahmad, R.R., Rohana, K., \& Jamaliah, M.K. (2013, April). Bantuan Rakyat Satu Malaysia (BR1M): Consumption pattern and the relationship between acceptances, perception towards government sincere incentives and political motives. Paper presented at 2nd International Islamic Business, Kuala Lumpur, Malaysia. Kuala Lumpur: International Islamic University Malaysia.

Akinyemi, O., Alege, P.O., Ajayi, O.O., Adediran, O.S., \& Urhie, E. (2017). A simulation of the removal of fuel subsidy and the performance of the agricultural sector in Nigeria using a dynamic Computable General Equilibrium Approach. Covenant Journal of Business and Social Sciences, 8(1), 60-70.

Barany, A., \& Grigonyte, D. (2015). Measuring fossil fuel subsidies. ECFIN Economic Brief, 40(March), 1-13.

Beaten, C., Gerasimchuk, I., Laan, T., Lang, K., Vis-Dunbar, D., \& Wooders, P. (2013). A guidebook to fossil-fuel subsidy reform: For policy-makers in Southeast Asia. Geneva: International Institute for Sustainable Development. Retrieved from https://www.iisd.org/library/ guidebook-fossil-fuel-subsidy-reform-policy-makers-southeast-asia

Bekhet, H.A. (2010). Ranking sectors changes of the Malaysian economy: Input-output approach. International Business Research, 3(1), 134-143. https://doi.org/10.5539/ibr.v3n1p107

Cervantes-Godoy, D., \& Dewbre, J. (2010). Economic importance of agriculture for poverty reduction (OECD Food, Agriculture and Fisheries Working Papers, No. 23). Paris, France: Organisation for Economic Co-operation and Development. Retrieved from https://doi. org/10.1787/ 5kmmv9s20944-en

Choo, Y.M. (2016, February). Domestic measures to enhance competitiveness of the palm oil industry. Paper presented at Reach and Remind 2016 Seminar, Kuching, Sarawak. Putrajaya: Ministry of Plantation Industries and Commodities. Retrieved from http://www.mpoc.org. $\mathrm{my} /$ upload/Domestic-Measures-to-Enhance-the-Competitiveness-of-the-Palm-Oil-Industry. pdf

Clements, B., Jung, H.S., \& Gupta, S. (2007). Real and distributive effects of petroleum price liberalization: The case of Indonesia. The Developing Economies, 45(2), 220-237. https://doi. org/10.1111/j.1746-1049.2007.00040.x

Cockburn, J., Robichaud, V., \& Tiberti, L. (2018). Energy subsidy reform and poverty in Arab countries: A comparative CGE-microsimulation analysis of Egypt and Jordan. Review of Income and Wealth, 64(s1), s249-s273. https://doi.org/10.1111/roiw.12309

Cooke, E.F.A., Hague, S., Tiberti, L., Cockburn, J., \& El Lahga, A.R. (2015). Estimating the impact on poverty of Ghana's fuel subsidy reform and a mitigating response. Journal of Development Effectiveness, 8(1), 105-128. https://doi.org/10.1080/19439342.2015.1064148

Dabla-Norris, E., Kochhar, K., Suphaphiphat, N., Ricka, F., \& Tsounta, E. (2015). Causes and consequences of income inequality: A global perspective (IMF Staff Discussion Note No. 15/13). Washington, DC: International Monetary Fund. Retrieved from https://www.imf.org/ en/Publications/Staff-Discussion-Notes/Issues/2016/12/31/Causes-and-Consequences-ofIncome-Inequality-A-Global-Perspective-42986

El-Katiri, L., \& Fattouch, B. (2015). A brief political economy of energy subsidies in the Middle East and North Africa (OIES Paper: MEP 11). Oxford: Oxford Institute for Energy Studies. Retrieved from https://doi.org/10.26889/9781784670214

Ellis, J. (2010). The effect of fossil-fuel subsidy reform: A review of modeling and empirical studies. Geneva: International Institute for Sustainable Development. Retrieved from https://www. iisd.org/library/effects-fossil-fuel-subsidy-reform-review-modelling-and-empirical-studies 
Feltenstein, A. (2017). Subsidy reform and implications for social protection: An analysis of IMF advice on food and fuel subsidies (IEO Background Paper BP/17-01/02). Washington, DC: International Monetary Fund.

Feng, K.S., Hubacek, K., Liu, Y., Marchán, E., \& Vogt-Schilb, A. (2018). Managing the distributional effects of energy taxes and subsidy removal in Latin America and the Caribbean. Applied Energy, 225(September), 424-436. https://doi.org/10.1016/j.apenergy.2018.04.116

Hamid, K.A., \& Rashid, Z.A. (2012). Economic impacts of subsidy rationalization Malaysia. In Y. Wu, X. Shi, \& F. Kimura (Eds.), Energy market integration in East Asia: Theories, electricity sector and subsidies (ERIA Research Project Report 2011-17). Jakarta: Economic Research Institute for ASEAN and East Asia. Retrieved from http://www.eria.org/publications/energy-marketintegration-in-east-asia-theories-electricity-sector-and-subsidies/

Hassan, A.A.G., Saari, M.Y., Utit, C., Hassan, A., \& Mukaramah, H. (2016). Estimating the impact of GST implementation on cost of production and cost of living in Malaysia. Jurnal Ekonomi Malaysia, 50(2), 15-30.

Holland, D., Figueroa, E., \& Gilbert, J. (2001). The role of agriculture and food processing in the Chilean economy: Results from an input-output analysis. Estudios de Economía, 28(2), 293308.

International Energy Agency (IEA), Organization of the Petroleum Exporting Countries (OPEC), Organization for Economic Co-operation and Development (OECD), \& World Bank. (2010). Analysis of the scope of energy subsidies and suggestions for the G-20 initiative. Washington, DC: World Bank. Retrieved from http://documents.worldbank.org/curated/ en/959281468160496244/Analysis-of-the-scope-of-energy-subsidies-and-suggestions-forthe-G-20-initiative

Jaafar, A.H., Salleh, N.H.M., \& Manaf, Z.A. (2015). Intersectoral linkages in oil palm industry between Malaysia and Indonesia. Jurnal Ekonomi Malaysia, 49(1), 25-35. http://dx.doi.org/ 10.17576/JEM-2015-4901-03

Kehinde, A., Kyade, K., Felix, A., Musibau, O., \& Ishola, A. (2012). Fuel subsidy, agricultural sector, petroleum, budgetary allocation. International Journal of Humanities and Social Science Invention, 1(1), 20-29.

Kosmo, M. (1987). Money to burn? The high costs of energy subsidies. Washington, DC: World Resource Institute. Retrieved from https://www.wri.org/publication/money-burn-high-costsenergy-subsidies

Laderchi, C.R. (2014). Transitional policies to assist the poor while phasing out inefficient fossil fuel subsidies that encourage wasteful consumption. Washington, DC: World Bank.

Löfgren, H., Harris, R.L., \& Robinson, S. (2002). A standard computable general equilibrium (CGE) model in GAMS. Washington, DC: International Food Policy Research Institute.

Malaysia Energy Information Hub Unit. (2018). Malaysia energy statistics handbook 2017. Putrajaya: Energy Commission.

Manzoor, D., Shahmoradi, A., \& Haqiqi, I. (2012). An analysis of energy price reform: A CGE approach. OPEC Energy Review, 36(1), 35-54. https://doi.org/10.1111/j.1753-0237.2011. 00200.x

Merrill, L., \& Chung, V. (2014). Financing the sustainable development goals through fossil-fuel subsidy reform: Opportunities in Southeast Asia, India and China. Geneva: International Institute for Sustainable Development. Retrieved from https://www.iisd.org/library/ financing-sustainable-development-goals-through-fossil-fuel-subsidy-reform-opportunities

Ministry of Agriculture Malaysia. (2011). Dasar agromakanan negara (2011-2020). Putrajaya: Author.

Ministry of Finance Malaysia. (2011). Economic report 2010/2011. Putrajaya: Author.

Ministry of Finance Malaysia. (2013). Economic report 2012/2013. Putrajaya: Author.

Ministry of Finance Malaysia. (2014). Economic report 2013/2014. Putrajaya: Author. 
Mukaramah, H., Zakariah, A.R., \& Azali, M. (2012). Constructing a social accounting matrix framework to analyse the impact of public expenditure on income distribution in Malaysia. Jurnal Ekonomi Malaysia, 46(2), 63-83.

Rentschler, J. (2016). Incidence and impact: The regional variation of poverty effects due to fossil fuel subsidy reform. Energy Policy, 96(September), 491-503. https://doi.org/10.1016/j. enpol.2016.06.025

Rentschler, J., \& Bazilian, M. (2017). Principles for designing effective fossil fuel subsidy reforms. Review of Environmental Economics and Policy, 11(1), 138-155. https://doi.org/10.1093/ reep/rew016

Rentschler, J., Kornejew, M., \& Bazilian, M. (2017). Fossil fuel subsidy reforms and their impacts on firms. Energy Policy, 108(September), 617-623. https://doi.org/10.1016/j.enpol.2017. 06.036

Saari, M.Y., Shuja, N., \& Rahman, I.A. (2013). Evaluation of impacts of the rise in energy prices on costs of production and living expenses in Malaysia. Malaysian Journal of Economic Studies, 50(1), 1-20.

Saari, M.Y., Radam, A., \& Abdullah, A.M. (2008). The impacts of increase in the domestic petroleum prices on cost production in the agricultural and agro-based sectors. International Journal of Business and Society, 9(1), 37-52.

Sayed, L.E., Sayegh, W., Saliba, E., \& Stephen, J. (2015). Fossil fuel subsidies in Lebanon: Fiscal, equity, economic and environmental impacts. Lebanon: United Nations Development Programme. Retrieved from http://climatechange.moe.gov.lb/viewfile. aspx?id=218

Siddiq, K., Minor, P.J., Grethe, H., Aguiar, A., \& Walmsley, T.L. (2015). Impacts on poverty of removing import subsidies in Nigeria (Policy Research Working Paper No. WPS7376). Washington, DC: World Bank. Retrieved from http://documents.worldbank.org/curated/en/ 977601468180545927/Impacts-on-poverty-of-removing-fuel-import-subsidies-in-Nigeria

Solaymani, S., Kardooni, R., Kari, F., \& Yusoff, S. (2014). Economic and environmental impacts of energy subsidy reform and oil price shock on the Malaysian transport sector. Travel Behaviour and Society, 2(2), 65-77. https://doi.org/10.1016/j.tbs.2014.09.001

Solaymani, S.,Kari, F., \& Zakaria, R.H. (2013). Evaluating the role of subsidy reform in addressing poverty levels in Malaysia: A CGE poverty framework. The Journal of Development Studies, 50(4), 556-569. https://doi.org/10.1080/00220388.2013.841888

Widodo, T., Sahadewo, G.A., Setiastuti, S.U., \& Chaerriyah, M. (2012). Impact of fuel subsidy removal on government spending. In Y. Wu, X. Shi, \& F. Kimura (Eds.), Energy market integration in East Asia: Theories, electricity sector and subsidies (ERIA Research Project Report 2011-17, pp. 173-206). Jakarta: Economic Research Institute for ASEAN and East Asia. Retrieved from http://www.eria.org/publications/energy-market-integration-in-east-asiatheories-electricity-sector-and-subsidies/ 


\section{Appendix}

Table A1. Definition of Notations

\begin{tabular}{|c|c|}
\hline Symbol & Description \\
\hline \multicolumn{2}{|l|}{ Set Indices } \\
\hline$a \in A$ & A set of activities \\
\hline$\alpha \in A L E O N(\subset A)$ & $\begin{array}{l}\text { A set of activities with a Leontief function at the top of the } \\
\text { technology nest }\end{array}$ \\
\hline$c \in C$ & A set of commodities (also referred to as $C^{\prime}$ and $c^{\prime}$ ) \\
\hline$c \in C D(\subset C)$ & A set of commodities with domestic sales of domestic output \\
\hline$c \in C D N(\subset C)$ & $\begin{array}{l}\text { Commodities without domestic market sales of domestic } \\
\text { output (complement of CD) }\end{array}$ \\
\hline$c \in C E(\subset C)$ & A set of export commodities (with domestic production) \\
\hline$c \in C E N(\subset C)$ & Non-exported commodities (complement of CE) \\
\hline$c \in C M(\subset C)$ & A set of imported commodities \\
\hline$c \in C M N(\subset C)$ & A set of non-imported commodities \\
\hline$c \in C X(\subset C)$ & A set of commodities with domestic output \\
\hline$f \in F\left(=F^{\prime}\right)$ & A set of factors \\
\hline$i \in H(\subset I N S D N G)$ & A set of households \\
\hline$i \in I N S$ & A set of institutions (domestic and the ROW) \\
\hline$i \in I N S D(\subset I N S)$ & A set of domestic institutions \\
\hline$i \in I N S D N G\left(=I N S D N G^{\prime} \subset I N S D\right)$ & A set of domestic non-governmental institutions \\
\hline \multicolumn{2}{|l|}{ Parameters } \\
\hline$c w t s_{c}$ & Weight of commodity $\mathrm{c}$ in the CPI index \\
\hline$d w t s_{c}$ & Weight of commodity $\mathrm{c}$ in the PPI index \\
\hline$i c a_{c, a}$ & Quantity of $c$ per unit of aggregate intermediate input $a$ \\
\hline int $a_{a}$ & Quantity of aggregate intermediate input per activity unit \\
\hline$i v a_{a}$ & Quantity of value-added per activity unit \\
\hline$p w e_{c}$ & f.o.b. export price (foreign currency) \\
\hline$p w m_{c}$ & c.i.f. import prices in foreign currency \\
\hline qdst & Quantity of stock change \\
\hline $\operatorname{shif}_{i, f}$ & Income share of domestic institutions $(i)$ from factor $f$ \\
\hline
\end{tabular}


Table A1. Continued

\begin{tabular}{|c|c|}
\hline Symbol & Description \\
\hline$s h i i_{i, i^{\prime}}$ & Share of net income of $i^{\prime}$ to $i\left(i \in\right.$ INSDNG; $\left.i^{\prime} \in I_{\text {INSDNG }}\right)$ \\
\hline$t a_{a}$ & Activity tax rate \\
\hline$t e_{c}$ & Export tax rate \\
\hline$t f_{f}$ & Direct tax rate for factor $f$ \\
\hline$t m_{c}$ & Import tariff rate \\
\hline$t q_{c}$ & $\begin{array}{l}\text { Sales tax rate (as share of composite price inclusive of sales } \\
\text { tax) }\end{array}$ \\
\hline$t r_{i, f}$ & Transfer from factor $f$ to institutions $(i)$ \\
\hline$t v a_{a}$ & Value-added tax rate for activity $a$ \\
\hline$q i n v_{c}$ & Base-year quantity of fixed investment demand \\
\hline $\operatorname{tins}_{i}$ & Exogenous rate of direct tax on domestic institutions (i) \\
\hline$\alpha_{c}^{q}$ & A shift parameter of Armington function \\
\hline$\alpha_{c}^{t}$ & A shift parameter of CET function \\
\hline$\alpha_{a}^{v a}$ & Efficiency parameter in the CES value-added function \\
\hline$\delta_{c}^{q}$ & A share parameter of Armington function \\
\hline$\delta_{c}^{t}$ & A share parameter of CET function \\
\hline$\delta_{f, a}^{v a}$ & $\begin{array}{l}\text { CES value-added function share parameter for factor } f \text { in } \\
\text { activity } a\end{array}$ \\
\hline$\rho_{a}^{v a}$ & CES value-added function exponent \\
\hline$\rho_{c}^{q}$ & An exponent of Armington function \\
\hline$\rho_{c}^{t}$ & An exponent of CET function \\
\hline$\theta_{a, c}$ & Output yield, $c$ per unit of activity $a$ \\
\hline \multicolumn{2}{|c|}{ Endogenous variables } \\
\hline$\overline{C P I}$ & Consumer price index ( $=0$ for base; exogenous variable) \\
\hline$D P I$ & PPI for domestically marketed output \\
\hline$E G O V$ & Government expenditures \\
\hline$E S A V_{e n t}$ & Enterprises' savings \\
\hline $\mathrm{QHOH}_{h}$ & Household consumption expenditures \\
\hline
\end{tabular}


Table A1. Continued

\begin{tabular}{|c|c|}
\hline Symbol & Description \\
\hline EXR & Exchange rate (domestic currency per foreign currency) \\
\hline GOVSHR & Share of government consumption in nominal absorption \\
\hline$G S A V$ & Government savings \\
\hline INVSHR & Investment share in nominal absorption \\
\hline$P A_{a}$ & Activity price (gross revenue per activity unit) \\
\hline$P D_{c}$ & $\begin{array}{l}\text { Domestic prices for commodity produced and sold } \\
\text { domestically }\end{array}$ \\
\hline$P E_{c}$ & Export price in domestic currency \\
\hline PINTA $_{a}$ & Price of aggregate intermediate input for activity $a$ \\
\hline$P M_{c}$ & Import price in domestic currency \\
\hline$P Q_{c}$ & Composite commodity price (including transaction costs) \\
\hline$P V A_{a}$ & Value-added prices (aggregate) \\
\hline$P X_{a, c}$ & Aggregate producer price for commodity $(C)$ \\
\hline$Q A_{a}$ & Activity quantity (level) \\
\hline$Q D_{c}$ & Quantity of domestic outputs sold domestically \\
\hline$Q E_{c}$ & Export quantity \\
\hline$Q F_{f, a}$ & Quantity demanded of factor $f$ from activity $a$ \\
\hline $\mathrm{QHOH}_{c, h}$ & Household consumption of marketed commodity $(c)$ \\
\hline$Q I N T A_{a}$ & Aggregate intermediate input quantity \\
\hline$Q I N T_{c, a}$ & Quantity of commodity $c$ (as intermediate input to activity $a$ ) \\
\hline$Q I N V_{c}$ & Quantity of fixed investment demand for commodity \\
\hline$Q M_{c}$ & Quantity of imported commodity \\
\hline$Q Q_{c}$ & $\begin{array}{l}\text { Composite supply (quantity of goods supplied to domestic } \\
\text { market) }\end{array}$ \\
\hline$Q V A_{a}$ & Value-added quantity (aggregate) \\
\hline$Q X_{a, c}$ & $\begin{array}{l}\text { Aggregate marketed quantity of domestic output of } \\
\text { commodity }\end{array}$ \\
\hline$T A B S$ & Total nominal absorption \\
\hline $\operatorname{TRNSFR}_{i, i^{\prime}}$ & Transfer from institutions $\left(i^{\prime}\right)$ to $(i)$ (both in the set INSDNG) \\
\hline
\end{tabular}


Table A1. Continued

\begin{tabular}{|c|c|}
\hline Symbol & Description \\
\hline$W A L R A S$ & The Walrasian (Saving-Investment is equal to zero) \\
\hline$W F_{f}$ & Average price of factor \\
\hline$Y F_{f}$ & Income of factor $f$ \\
\hline$Y G O V$ & Government revenue \\
\hline $\mathrm{YHOH}_{h}$ & Household incomes \\
\hline$Y I F_{i, f}$ & Income to domestic institutions ( $i$ ) from factor $f$ \\
\hline \multicolumn{2}{|c|}{ Exogenous variables } \\
\hline$M P S_{i}$ & $\begin{array}{l}\text { Marginal propensity to save for domestic non-governmental } \\
\text { institution }\end{array}$ \\
\hline$D M P S$ & Change of savings rates on domestic institutions ( $=0$ for base) \\
\hline$\overline{\operatorname{DTINS}_{i}}$ & Change in tax share on domestic institution (=0 for base) \\
\hline$\overline{F S A V}$ & Foreign savings (foreign currency) \\
\hline$\overline{I A D J}$ & Investment adjustment factor \\
\hline$\overline{M P S A D J}$ & Savings rate scaling factor ( $=0$ for base) \\
\hline$\overline{Q F S}_{f}$ & Quantity of factor supply \\
\hline$\overline{T I N S A D J}$ & Scaling factor of direct tax (=0 for base) \\
\hline$\overline{W F D I S T}_{f, a}$ & Wage distortion factor for factor $f$ in activity $a$ \\
\hline $\operatorname{TINS}_{i}$ & Direct tax rate for institution $i(i \in$ INSDNG) \\
\hline
\end{tabular}

